\title{
ROLES DEFINED THROUGH LANGUAGE: A COMPARATIVE ANALYSIS OF NOUNS DENOTING FAMILY RELATIONS IN AR- MENIAN, ITALIAN AND ENGLISH LANGUAGES
}

\section{OFELIA GRIGORYAN}

Various research questions in the field of sociolinguistics are in the center of attention nowadays. Scientists of different disciplines examine the thematic issues and try to give explanations related to the descriptions of the societies or the languages. This research is also an attempt to find out the peculiarities of societies by comparative analysis of languages. The main purpose of the article is to analyze the nouns denoting family relations in Italian, Armenian and English languages.

Although the scientific study of language is mainly implemented in the frames of linguistics, its scientific branches also study language from different aspects. Being the discipline that aims to understand the interconnections and interactions between the language and the society in general, sociolinguistics has a wide area of research. Scholars from a range of disciplines have foregrounded a view of language in the development of their distinct approaches to the study of human thought and action vis-a-vis social and cultural factors ${ }^{1}$.

Examining the connections between language and family, it is important to have a look at the approach of the anthropologist Cl. Levi - Strauss who spoke about the way linguistic rules can affect our understanding of structural relations, and especially structure of kinship. "...marriage regulations and kinship nomenclature may afford us a workable image of the type of relationships that could have existed at a very early period in the development of language, between human beings and their words" 2 .

Although L. Strauss's anthropological view of the family relationships are of basic significance for deeply understanding kinship features, it will be specifically useful to adopt a sociological viewpoint in the frameworks of this study. Before going through the pure sociological approach, it is fair to mention the idea that speakers draw on historical and linguistic relationships as resources in designing their personal identity and relationships during talk ${ }^{3}$. So, through the way of language usage the communication is being formed which also forms

\footnotetext{
${ }^{1}$ Coupland, N., Sarangi, S. \& Candlin, C., Sociolinguistics and Social Theory, Longman, University of Michigan, 2001, p. 30.

${ }^{2}$ Levi-Strauss, Cl., Language and the Analysis of Social Laws, American Anthropologist, New Series, Vol. 53, No. 2, 1951, pp. 155-163.

${ }^{3}$ Coupland, N., Style: Language variation and identity, Cambridge, New York: Cambridge University Press, 2007, p. 128.
} 
the relationship style.

Continuing with the structuralistic approach, British sociologist Anthony Giddens suggests the Structuration theory where he emphasizes a fundamental role to language explaining "...language use is embedded in the concrete activities of day-to-day life and is in some sense partly constitutive of those activities" $"$.

The theorist states that "some social problems can be derived through studying the recursive qualities of speech and language. As the language reflects the form of thinking, when people speak the same language, they all share the same rules and linguistic practices, give or take a range of relatively minor variations",

The new generations usually adopt the ways of thinking through socialization, in other words - the process of learning to behave in a way that is acceptable to society ${ }^{6}$. Learning the native language is also a part of socialization as a result of which the person adopts the linguistic patterns in a certain society. After learning a language, the person starts to think in some social and linguistic frames, as it expands the cognitive skills.

The structuration theory of A. Giddens became a methodological basis for researches in a number of fields. According to M. Poole, group communication was one of the first areas to be studied using structuration theory ${ }^{7}$. He also referred to his early works ${ }^{8}$, arguing that the small group should be the fundamental unit for communication research.

By using the structuration theory the researchers try to solve the micromacro barrier in organizational researches, as well. Before that, the researchers offer the aproaches to study either the micro phenomena, for example decisions, interactions, or macro systems such as institutions. Meanwhile, the structuration theory has increasingly reconceptualized this problem by framing social structure as an assemblage of rules and resources on the one hand, and paying attention on interactions, on the other hand ${ }^{9}$. It is also valuable to study the organizations through structuration theory as it helps to examine the dynamics of organizational change and to understand the organization as a process ${ }^{10}$.

${ }^{4}$ Giddens, A. The Constitution of Society. Outline of the Theory of Structuration. University of California Press, 1984.

${ }_{6}^{5}$ Ibid. p. 24.

6 Oxford Dictionary, https://en.oxforddictionaries.com/definition/socialization, accessed 10.11.2019.

${ }_{7}^{7}$ Poole, M., Structuration Research on Group Communication, Management Communication Quarterlv. 27. 4. 2013. pp. 607-614.

${ }_{8}$ Poole, M. The Small Group Should Be the Fundamental Unit of Communication Research. In Trent. J. (Ed.), Communication: Views from the Helm for the 21st Century, Boston, MA: Allyn \& Bacon, 1997, pp. 94-97.

${ }^{9}$ McPhee, R., Poole, M., Iverson, J., Structuration Theory In Putnam, L. \& Mumby, D. (Ed.), The SAGE Handbook of Organizational Communication: Advances in Theory, Research and Methods, 2014, pp. 75-101.

${ }^{10}$ Albano, R., Masino, G., Magi, B., The Relevance of Giddens' Struturation Theory for Organizational Research, TAO Digital Library - Bologna, 2010. 
M. Jones and H. Karsten state that Giddens's theory has been cited in more than 300 papers in the Information Systems research field. These papers have contributed to the literature by illustrating the specific insights of the structuration theory, by supporting non-dualistic analyses of information system phenomena and by providing new approaches or perspectives that enrich the understanding of the phenomena ${ }^{11}$.

Although some researchers think that structuration theory involve concepts that operate at a high level of abstraction, hence it is difficult to adapt it to any research method and to apply empirically ${ }^{12}$, it will be worth to use it in the frames of the current research. The role that is given to the language in this theory corresponds with the idea of the research - people in the same group share common linguistic practices which is reflected in their way of thinking.

Besides of the above-described theory, current research is also based on the ideas of a British sociologist Basil Bernstein. Speaking of the role of the language in the society, he claims that the word moderates between the expression of feeling and its social recognition, in other words, the verbalization of a feeling gains a particular value ${ }^{13}$. Although this can be found in all societies, the major determining factor here is not the size of vocabulary, but rather the way the social emphasis on an aspect of the language structure transforms interrelations between feeling and thought. The theorist is sure that the language exists in relation to a desire to express and communicate: "...the mode of a language structure - the way in which words and sentences are related - reflects a particular form of the structuring of feeling and so the very means of interaction and response to the environment" ${ }^{14}$.

Since Bernstein's ideas spread throughout the world, it resulted in some interpretations by other theorists, one of which, namely W. Zhao, stated, that "...Bernstein can be viewed as one of the leading figures who have exerted great impact upon our thinking about language outside the linguistics circle" ${ }^{\text {"15 }}$. He also referred to linguist M. Halliday who mentioned that Bernstein seemed unique among sociologists in emphasizing the key role of language in social processes, especially in socialization and cultural transmissions ${ }^{16}$.

One of the key ideas of B. Bernstein that is reflected in the current study is

${ }^{11}$ Jones, M. R., \& Karsten, H., Giddens's Structuration Theory and Information Systems Research. MIS Quarterly, 32(1), 2008, 127-157.

${ }_{12}$ Pozzebon, M. \& Pinsonneault, A., Challenges in Conducting Empirical Work Using Structuration Theory: Learning from IT research. In: Organization Studies 26 (9), 2005, pp. 13531376.

${ }^{13}$ Bernstein, B. Class, Codes and Control (Volume 1) - Theoretical Studies Towards a Sociology of Language. London: Routledge \& Kegan Paul., 1971.

${ }_{15}^{14}$ Ibid. p. 19.

${ }^{15}$ Zhao, W, The Implications of Bernstein's Theory of Codes on Contemporary Chinese Education, Canadian Social Science Vol. 10, No. 6, 2014, pp. 99-103.

${ }^{16}$ Zhao, W The Implications of Bernstein's Theory of Codes on Contemporary Chinese Education, Canadian Social Science Vol. 10, No. 6; more detailed in: Halliday, M. (1995). Language and the Theory of Codes. In A. Sadovnik (Ed.). Knowledge and Pedagogy: The Sociology of Basil Bernstein. Westport, CT: Greenwood Publishing Group., 2014. 
the differentiation of language codes. According to K. Maton and J. Muller, the concept of code has undergone several transmutations in Bernstein's work although the underlying conceptual continuum has remained stable, tracing a range from 'less specialized' to 'more specialized' 17 .

B. Berstein distinguished two types of codes - elaborated and restricted. He characterized the codes as functions of a particular form of social relationship or, more generally, qualities of social structure ${ }^{18}$. In case of usage of the elaborated codes, there is a huge diversity of meanings and each time the listener is obliged to choose between alternatives of meanings. So, the way a speech is formed becomes a very important factor. While explaining his theory in frames of the distinction between classes and their linguistic patterns, B. Bernstein anticipated that the elaborated codes were mostly used by representatives coming from middle and upper classes ${ }^{19}$.

The restricted codes took up a wider layer of society, so it is used even more commonly. The speech model for this code is universal as its use depends on the characteristics of a form of social relationship, which can be used at any point in the social structure ${ }^{20}$. As a result, the meaning becomes more predictable in case of usage of restricted codes. Thus, comparing the categories of codes, Bernstein states that "...if a restricted code facilitates the construction and exchange of 'social' symbols, then an elaborated code facilitates the construction and exchange of 'individuated' symbols" ${ }^{21}$.

Language is considered as one of the most important means of initiating, synthesizing, and reinforcing ways of thinking, feeling and behavior, which are functionally related to the social group ${ }^{22}$. By studying restricted codes, the whole society can be understood, as these are the codes which are used by the members of all social groups.

In case of comparison of languages, as it is done in this research, the theory of B. Bernstein is particularly interesting, inasmuch as he referred to Bruner $^{23}$ who considered that a range of experience may be differentiated in the lexicon of one language and undifferentiated in another and there is the role of cultural usages and symbolic forms and means which made a contribution to the understanding ${ }^{24}$.

So, in the frames of current research the structuration theory is interesting for its given role to the language in society - the practices that are reproduced in

\footnotetext{
${ }^{17}$ Maton, K. \& Muller, J., A sociology for the transmission of knowledges, in Christie, F. \& Martin, J. (eds) Language, Knowledge and Pedagogy. London, Continuum, 2007, pp. 14-33.

${ }^{18}$ Bernstein, B. Class, Codes and Control (Volume 1) - Theoretical Studies Towards a Sociology of Language. London: Routledge \& Kegan Paul, 1971, p. 59.

19 Ibid.

${ }^{20}$ Ibid. p. 60.

${ }^{21}$ Ibid. p. 59.

${ }^{22}$ Bernstein, B., A Public Language: Some Sociological Implications of a Linguistic Form,
} The British Journal of Sociology, Vol. 61, 2010.

${ }^{23}$ Bruner, J., Goodrow, J. and Austin, A., A Study of Thinking, Wiley, 1957.

${ }^{24}$ Davis, A. et al. Intelligence and Cultural Differences, University of Chicago Press, 1951. 
the society through linguistic patterns. From the language code theory, the idea of restricted codes is valuable, as they are the ones which are used by all members of society like the nouns which are observed during the research.

As it was already mentioned, the aim of the research is to find out the differences of nouns denoting family relations in 3 languages - Armenian, Italian and English. The choice of languages is mainly conditioned by the interest to find out either the similarity of nations - Armenians and Italians, about which a huge number of stereotypes/thoughts exist, is somehow reflected in the languages or not. English is chosen as an "intermediary" language - international one which is mainly neutral and widely-spoken all over the world - to compare the Italian and the Armenian in one common language. While comparing the existence of these nouns in the languages, it becomes obvious that some of them does not exist at all, the others are used in various forms and the third ones have the exact equivalents and so on. Meanwhile, the aim is not only to characterize the nouns and to speak about the existence of this or that word in a language, but to give explanations and to mark possible reasons of it. Some explanations become clear in the result of comparison of societies, traditions. Hence, it is interesting to connect the linguistic peculiarities of these nouns with the social aspect.

Meanwhile, the explanations are based on sociological theories. For example, the theory of language code, according to which the nouns denoting family relations can be considered as "restricted codes" - commonly used ones. Giddens's theory of structuration is also methodological basis for the research as it explains the structure with the rules and resources used by actors which are reproduced during interaction. The core role in the interaction plays the language which itself motivates some way of thinking.

Except for the theories it is important to define the main categories. During current research the term "role" is understood as a behavior that is expected of any individual occupying a particular social position ${ }^{25}$. A "role-relationship" is defined as those aspects of a relationship that consist of reciprocal role expectations of each person concerning the other ${ }^{26}$.

As it was already mentioned, "language is considered here as one of the most important means of initiating, synthesizing, and reinforcing ways of thinking, feeling and behavior, which are functionally related to the social group" ${ }^{27}$. Restricted codes are used by whole society, so this is the language through which we can study the society. According to the definition, the "code" itself "means a regulative principle, tacitly acquired, which selects and integrates

${ }^{25}$ Bott, E. Family and Social Network: Roles, Norms and External Relationships in Ordinary Urban Families, Routledge, 2001, p.3.

${ }^{26}$ Ibid. p.3.

${ }^{27}$ Bernstein, B., A Public Language: Some Sociological Implications of a Linguistic Form, The British Journal of Sociology, Vol. 61, 2010. 
meanings, forms of realizations, and evoking contexts" ${ }^{, 28}$.

And finally, here we suggest an approach which defines family containing not only individuals but relationships, which imply connections, bonds, attachments and obligations among people ${ }^{29}$. Family can be understood in its extended interpretation and not only as a social group who share a common residence, but also a social group the members of which have achieved a significant degree of emotional closeness and sharing - people who relate to each other by blood, marriage, or adoption, as it is based symbolically on the biological model of kinship.

As it was already mentioned, the nouns denoting family relations in 3 languages differ from each other. Before analyzing its reasons and giving some explanations, the list of observing nouns will be presented.

So, the list of nouns denoting family relations in Armenian, Italian and English languages is as follows:

\begin{tabular}{|c|c|c|}
\hline Armenian & English & Italian \\
\hline Uujp [mayr] - mother & Mother & La madre \\
\hline Zujp [hayr] - father & Father & Il padre \\
\hline Ounn [tsnogh] - parents & Parents & I genitori \\
\hline Pnıjn [quyr] - sister & Sister & La sorella \\
\hline $\begin{array}{l}\text { Enpuijn [yeghbayr] - } \\
\text { brother }\end{array}$ & Brother & Il fratello \\
\hline \multicolumn{3}{|c|}{ Siblings } \\
\hline 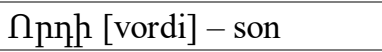 & Son & Il figlio \\
\hline nuunn [ustr] - son & Son & Il figlio \\
\hline $\begin{array}{l}\text { ?nıuunp [dustr] - daugh- } \\
\text { ter }\end{array}$ & Daughter & La figlia \\
\hline \multirow[t]{2}{*}{ :quulul [zavak] - child } & Child & Il bambino (male) \\
\hline & & La bambina (female) \\
\hline \multirow[t]{2}{*}{ Epthuu [yerekha] - child } & Child & Il bambino/La bambina \\
\hline & Grandparents & I nonni \\
\hline Suun [tat] - grandmother & Grandmother & La nonna \\
\hline $\begin{array}{l}\text { Utid uujp [mets mayr] - } \\
\text { grandmother }\end{array}$ & Grandmother & La nonna \\
\hline Tuuu [pap] - grandfather & Grandfather & Il nonno \\
\hline $\begin{array}{l}\text { Utid huup [mets hayr] - } \\
\text { grandfather }\end{array}$ & Grandfather & Il nonno \\
\hline \multicolumn{3}{|c|}{ Great - grandparents } \\
\hline & Great-grandmother & La bisnonna \\
\hline & Great-grandfather & Il bisnonno \\
\hline Onn [thor] - grandchild & Grandchild & Il nipote \\
\hline
\end{tabular}

\footnotetext{
${ }^{28}$ Bernstein, B. Class, Codes and Control: Volume 4 - The Structuring of Pedagogic Discourse, 1990, p. 101.

${ }^{29}$ Newman, D., Grauerholz, L. Sociology of Families, SAGE Publications, 2002, p. 7.
} 


\begin{tabular}{|c|c|c|}
\hline fnn [thor] - grandson & Grandson & Il nipote \\
\hline $\begin{array}{l}\text { Onninuhh [thornuhi] - } \\
\text { granddaughter }\end{array}$ & Granddaughter & La nipote \\
\hline $\begin{array}{l}\text { Onn [tsor] - great- } \\
\text { grandchild }\end{array}$ & Great - grandchild & \\
\hline $\begin{array}{l}\text { Onn [tsor] - great- } \\
\text { grandson }\end{array}$ & Great - grandson & Pronipote \\
\hline $\begin{array}{l}\text { Onnqunhh [tsornuhi] - } \\
\text { great-grandddaughter }\end{array}$ & Great - granddaughter & Pronipote \\
\hline $\begin{array}{l}\text { Znpupnusn [horaquyr] - } \\
\text { aunt (sister of father) }\end{array}$ & Aunt & La zia \\
\hline $\begin{array}{l}\text { Znpuppne uufnuuhi } \\
\text { [horaqroj amusin] - hus- } \\
\text { band of your aunt }\end{array}$ & Uncle & Lo zio \\
\hline $\begin{array}{l}\text { Unpupnujn [moraquyr] } \\
\text { - aunt (sister of mother) }\end{array}$ & Aunt & La zia \\
\hline $\begin{array}{l}\text { Unpuppng uúntuhi } \\
\text { [moraqroj amusin] - hus- } \\
\text { band of your aunt }\end{array}$ & Uncle & Lo zio \\
\hline $\begin{array}{l}\text { Znplinpuup } \\
\text { [horyeghbayr] - uncle } \\
\text { (brother of father) }\end{array}$ & Uncle & Lo zio \\
\hline $\begin{array}{l}\text { Znptipnn lhi } \\
\text { [horeghbor kin] - wife of } \\
\text { your uncle }\end{array}$ & Aunt & La zia \\
\hline $\begin{array}{l}\text { Unplinpujn } \\
\text { [moryeghbayr] - uncle } \\
\text { (brother of mother) }\end{array}$ & Uncle & Lo zio \\
\hline $\begin{array}{l}\text { Unplinnn lihi [mo- } \\
\text { reghbor kin] - wife of } \\
\text { your uncle }\end{array}$ & Aunt & La zia \\
\hline $\begin{array}{l}\text { Ptinh [qeri] - uncle } \\
\text { (brother of mother) }\end{array}$ & Uncle & Lo zio \\
\hline $\begin{array}{l}\text { Ptnulyhi [qerakin] - } \\
\text { wife of your uncle } \\
\text { (brother of mother) }\end{array}$ & Aunt & La zia \\
\hline $\begin{array}{l}\text { Qupuhl [zarmik] - } \\
\text { cousin (male) }\end{array}$ & Cousin & Il cugino \\
\hline \multirow{6}{*}{$\begin{array}{l}\text { Qupunnhh [zarmuhi] - } \\
\text { cousin (female) }\end{array}$} & Cousin & La cugina \\
\hline & Second cousin & $\begin{array}{l}\text { Il cugino di secondo } \\
\text { grado (male) }\end{array}$ \\
\hline & & $\begin{array}{l}\text { La cugina di second } \\
\text { grado (female) }\end{array}$ \\
\hline & \multicolumn{2}{|l|}{ Third cousin } \\
\hline & Nephew & Il nipote \\
\hline & Niece & La nipote \\
\hline Unnullhg [koghakic] - & Spouse & Il coniuge (male) \\
\hline
\end{tabular}


Uuntuhqutup [amusin-

ner] - wife and husband

Uúnıuhq [amusin] husband

\begin{tabular}{|c|c|c|}
\hline ५h\{ [kin] - wife & Wife & La moglie \\
\hline \multirow{2}{*}{$\begin{array}{l}\text { Suu }[\text { tal }] \text { - sister of hus- } \\
\text { band }\end{array}$} & Sister - in-law & La cognata \\
\hline & & $\begin{array}{l}\text { Il cognato (husband of } \\
\text { husband's sister) }\end{array}$ \\
\hline $\begin{array}{l}\text { Stiqn [tegr] - brother of } \\
\text { husband }\end{array}$ & Brother - in - law & Il cognato \\
\hline $\begin{array}{l}\text { Stiqpulhif [tegrakin]- } \\
\text { wife of husband's brother }\end{array}$ & & La cognata \\
\hline \multirow{2}{*}{$\begin{array}{l}\text { Uutinduuq [anerdzag] - } \\
\text { brother of wife }\end{array}$} & Brother - in- law & Il cognato \\
\hline & & $\begin{array}{l}\text { La cognata (wife of } \\
\text { wife's brother) }\end{array}$ \\
\hline $\begin{array}{l}\text { Ptilp [qeni] - sister of } \\
\text { wife }\end{array}$ & Sister - in - law & La cognata \\
\hline $\begin{array}{l}\text { Ptiquiluul [qenakal] - } \\
\text { husband of wife's sister }\end{array}$ & & Il cognato \\
\hline \multirow{2}{*}{$\begin{array}{l}\text { Fuiquiuun [badganagh] } \\
\text { - husband of wife's sister }\end{array}$} & & Il cognato \\
\hline & Parents - in- law & I suoceri \\
\hline $\begin{array}{l}\text { Ulikunıp [skesur]- } \\
\text { mother of husband }\end{array}$ & Mother - in - law & La suocera \\
\hline $\begin{array}{l}\text { Ulikupuup [skesrayr] - } \\
\text { father of husband }\end{array}$ & Father - in- law & Il suocero \\
\hline $\begin{array}{l}\text { Uitip [aner] - father of } \\
\text { wife }\end{array}$ & Father - in- law & Il suocero \\
\hline $\begin{array}{l}\text { Qnpuily [zoqanch] - } \\
\text { mother of wife }\end{array}$ & Mother- in- law & La suocera \\
\hline Zupu [hars] - wife of son & Daughter - in - law & La nuora \\
\hline $\begin{array}{l}\text { Фtuu [pesa] - husband } \\
\text { of daughter }\end{array}$ & Son - in - law & Il genero \\
\hline $\begin{array}{l}\text { Zupu [hars] - wife of } \\
\text { brother }\end{array}$ & Sister - in - law & La cognata \\
\hline $\begin{array}{l}\text { Thuu [pesa] - husband } \\
\text { of sister }\end{array}$ & Brother - in - law & Il cognato \\
\hline $\begin{array}{l}\text { Iunpp dinnilip [khorth } \\
\text { tsnoghner] - stepparents }\end{array}$ & Stepparents & \\
\hline \multirow{2}{*}{$\begin{array}{l}\text { Iunpp hujn [khorth hayr] } \\
\text { - stepfather }\end{array}$} & Stepfather & Il patrigno \\
\hline & Stepfather & Padre acquisito \\
\hline Iunpp uujn [khorth & Stepmother & La matrigna \\
\hline
\end{tabular}

\begin{tabular}{|c|c|c|}
\hline Чhi [kin] - wife & Wife & La moglie \\
\hline \multirow{2}{*}{$\begin{array}{l}\text { Suul }[\mathrm{tal}]-\text { sister of hus- } \\
\text { band }\end{array}$} & Sister - in-law & La cognata \\
\hline & & $\begin{array}{l}\text { Il cognato (husband of } \\
\text { husband's sister) }\end{array}$ \\
\hline $\begin{array}{l}\text { Stiqn [tegr] - brother of } \\
\text { husband }\end{array}$ & Brother - in - law & Il cognato \\
\hline $\begin{array}{l}\text { Stiqnulyhi [tegrakin] - } \\
\text { wife of husband's brother }\end{array}$ & & La cognata \\
\hline \multirow{2}{*}{$\begin{array}{l}\text { U\{tipduuq [anerdzag] - } \\
\text { brother of wife }\end{array}$} & Brother - in- law & Il cognato \\
\hline & & $\begin{array}{l}\text { La cognata (wife of } \\
\text { wife's brother) }\end{array}$ \\
\hline $\begin{array}{l}\text { ptup [qeni] - sister of } \\
\text { wife }\end{array}$ & Sister - in - law & La cognata \\
\hline $\begin{array}{l}\text { Ptiuuluų [qenakal] - } \\
\text { husband of wife's sister }\end{array}$ & & Il cognato \\
\hline \multirow{2}{*}{$\begin{array}{l}\text { Furquiuun [badganagh] } \\
\text { - husband of wife's sister }\end{array}$} & & Il cognato \\
\hline & Parents - in- law & I suoceri \\
\hline $\begin{array}{l}\text { Ultiunıp [skesur] - } \\
\text { mother of husband }\end{array}$ & Mother - in - law & La suocera \\
\hline $\begin{array}{l}\text { Ultiunujp [skesrayr] - } \\
\text { father of husband }\end{array}$ & Father - in- law & Il suocero \\
\hline $\begin{array}{l}\text { Uilip [aner] - father of } \\
\text { wife }\end{array}$ & Father - in- law & Il suocero \\
\hline $\begin{array}{l}\text { Qnpuide [zoqanch]- } \\
\text { mother of wife }\end{array}$ & Mother- in- law & La suocera \\
\hline Zupu [hars] - wife of son & Daughter - in - law & La nuora \\
\hline $\begin{array}{l}\text { Фtuu [pesa] - husband } \\
\text { of daughter }\end{array}$ & Son - in - law & Il genero \\
\hline $\begin{array}{l}\text { Zupu [hars] - wife of } \\
\text { brother }\end{array}$ & Sister - in - law & La cognata \\
\hline $\begin{array}{l}\text { Фtuu [pesa] - husband } \\
\text { of sister }\end{array}$ & Brother - in - law & Il cognato \\
\hline $\begin{array}{l}\text { IUnnp dinnilitp [khorth } \\
\text { tsnoghner] - stepparents }\end{array}$ & Stepparents & \\
\hline \multirow{2}{*}{$\begin{array}{l}\text { IUnpp hujp [khorth hayr] } \\
\text { - stepfather }\end{array}$} & Stepfather & Il patrigno \\
\hline & Stepfather & Padre acquisito \\
\hline IUnpp uuujn [khorth & Stepmother & La matrigna \\
\hline
\end{tabular}

I coniugi

Il marito

Husband

La moglie

Il cognato (husband of husband's sister

La cognata

wife of husband's brother

Uitinduuq [anerdzag] -

La cognata (wife of

wife's brother)

Ptip [qeni] - sister of

wife

Ptiuulyul [qenakal] -

husband of wife's sister

furquiuun [badganagh]

Parents - in- law I suoceri

Ultiuntp [skesur] -

Father - in- law

La coniuge (female) 


\begin{tabular}{|c|c|c|}
\hline mayr] - stepmother & & \\
\hline & Stepmother & Madre acquisita \\
\hline $\begin{array}{l}\text { funpp tiphuu [khorth } \\
\text { yerekha] - stepchild }\end{array}$ & Stepchild & \\
\hline $\begin{array}{l}\text { IUnpp unqu [khorth tgha] } \\
\text { - stepson }\end{array}$ & Stepson & Il figliastro \\
\hline $\begin{array}{l}\text { IUnpp unghl [khorth } \\
\text { aghjik] - stepdaughter }\end{array}$ & Stepdaughter & La figliastra \\
\hline funpp pnujn [khorth & Stepsister & La sorellastra \\
\hline & Stepsister & Sorella acquisita \\
\hline Iunpp tinpujp [khorth & Stepbrother & Il fratellastro \\
\hline & Stepbrother & Fratello acquisito \\
\hline & Foster parents & Genitori adottivi \\
\hline & Foster parents & Genitori affidatari \\
\hline & Foster father & Padre adottivo \\
\hline & Foster father & Padre affidatario \\
\hline & Foster mother & Madre adottiva \\
\hline & Foster mother & Madre affidataria \\
\hline 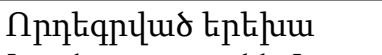 & Foster child & \\
\hline & Foster son & Figlio adottivo \\
\hline & Foster daughter & Figlia adottiva \\
\hline $\begin{array}{l}\text { fuulnn [qavor] - godfa- } \\
\text { ther }\end{array}$ & Godfather & Il padrino \\
\hline $\begin{array}{l}\text { Puulnplihi [qavorkin] - } \\
\text { godmother }\end{array}$ & Godmother & La madrina \\
\hline $\begin{array}{l}\text { Yqupuhujn [knqahayr] - } \\
\text { godfather }\end{array}$ & Godfather & Il padrino \\
\hline $\begin{array}{l}\text { Yipuufujp [knqamayr] - } \\
\text { godmother }\end{array}$ & Godmother & La madrina \\
\hline Uuquhl [sanik] - god- & Godchild & Il figlioccio (male) \\
\hline & Godchild & La figlioccia (female) \\
\hline
\end{tabular}

The list provided above shows that the equivalents in 3 languages do not completely match each other: there are some nouns which do not exist in one of the languages, some other nouns have various equivalents, the others are similar in 2 languages but are different in the third one. Thus, the empirical part will be an attempt to show the interconnections between these nouns and to give some explanations.

Beginning from the most used nouns like "mother", "father", "parents", "sister" and "brother", it becomes obvious that all these nouns exist in 3 languages, except for the word "siblings" which is used to speak about the brother- 
sister relation in English. While speaking about the "brothers" or "sisters", the equivalents ("fratelli", "sorelle", "pnujptip" (quyrer), "tinpuupitip" (yeghbayrner)") are used, but not the word "siblings" - in Armenian and in Italian the noun is replaced with the usage of just "brother-sister". The words "mother" and "father" have many short, casual varieties, like mommy, dad, uuu (mam), uuuu (pap), mamma, etc. The main attention must be paid on the short version of father in Italian, and not to confuse the word "papà" with "pappa" which is used to address the Pope.

It is interesting that there is no word equivalent to "grandparents" in Armenian, so people usually say "grandmother-grandfather". In Armenian the words "great-grandmother" and "great-grandfather" do not exist at all, "greatgrandparents" does not exist in Italian, as well. The words "grandmother" and "grandfather" have synonyms in Armenian, which are literally translated as "big mother" and "big father" and are widely used by western Armenians. The word "child" as well as just describing a person of a small age is used to describe the family relation between the child and the parents. In Armenian there is another word "quululy" ("zavak") which is used as a synonym to "child". If in Armenian for both female and male cases people just say "child", in Italian it differs "il bambino" (for male) and "la bambina" (for female). The nouns "son" and "daughter" have the same root in Italian and are used with different articles and suffixes - "il figlio", "la figlia". Some gender issues occur while looking at the Italian and the Armenian versions of the "grandchild-grandson-granddaughter". The problem is that in Armenian and in Italian the word "grandchild" is similar to "grandson - "il nipote" and "pnn" ("thor")", so the equivalents to the word "grandson" are used both in case of the male grandchild and the grandchild in general. The female versions are formed with the article "la" in Italian and with the suffix "nıhh" ("uhi"- the suffix that is used in cases to make the noun female, like "-essa" in Italian) in Armenian. And the same is for "greatgrandchild".

In Italian and in English languages the words "aunt" and "uncle" are used to describe both mother's and father's sister and brother, meanwhile in Armenian there are 2 different words for that, e.g. hnpupnujn [horaquyr] for father's sister and Unpupnıjn [moraquyr] for mother's sister. To describe mother's brother, there are even 2 words - the one with standard structure, composed of the words "mother-brother - unptippujp [moryeghbayr]" and short, casual version - ptinh [qeri]. In Italian and in English "zio - uncle" has four meanings: the brother of one of your parents, or the husband of your aunt ${ }^{30}$ (both mother's sister and father's sister). "Aunt" in English means sister of your mother or father, or the wife of your uncle ${ }^{31}$ and the same is for "zia" in Italian. Meanwhile

${ }^{30}$ Macmillan Dictionary, https://www.macmillandictionary.com/thesaurus-category/british/unclesand-aunts-and-cousins, accessed 10.11.2019.

${ }^{31}$ Ibid. 
in Armenian it is not so - the married partner of a person's aunt or uncle is named like "the wife of uncle" or "the husband of aunt" and is not turned to "aunt" or "uncle". There is only one word - ptinulhin [qerakin] which literally again means "wife of uncle" but is used as a separate word mainly because the second, non-standard version of "uncle" in Armenian is flexible word which is easy to decline the noun during the speech. It is also interesting that in Armenian people use the words "aunt and uncle (especially mother's sister and father's brother)" to speak with strangers/unknown them people.

While examining the word "cousin", it becomes obvious that in Italian it has the equivalents for both male and female nouns - "il cugino" and "la cugina". In Armenian there are some formal words like "qupulhl [zarmik]" and "qupuñhp [zarmuhi]" which usually are not used in everyday speech. People can call them just brother/sister, but not all people do so. So, in Armenian talking about "first cousins", people use, for example, the son of my aunt, etc. People also use the Russian equivalent of these words. In English each number in front of the word "cousin" corresponds to going another generation down both sides of the family tree - second cousins, third cousins and so on ${ }^{32}$. In Italian this relationship is explained by "il cugino di secondo grado (male)" or "la cugina di secondo grado (female)". In Armenian the second generation below the level of siblings is also characterized by the Russian word. In Armenian people use this just for mentioning the existence of blood relationship (counting until 7). People are not allowed to get marry in this case. In English first cousins can be classified two ways: cross- or ortho-cousins and patrilateral or matrilateral. Ortho-cousins are children of two sisters or two brothers; crosscousins are children of a sister and brother. Patrilateral cousin is your relative through your father (your father's brother or sister); and matrilateral cousin through your mother (your mother's brother or sister) ${ }^{33}$. Differentiation of such kind does not exist in Armenian at all. To describe the relation to son/daughter of a person's sister/brother Italians use the same word as for "nipote" - "grandson" and "granddaughter", which are the equivalents of the English "niece" and "nephew". In Armenian the words describing these relations do not exist as separate words and are described by saying "son/daughter of sister/brother". Maybe this is because Armenians mostly prioritize the roles of their sisters and brothers while speaking about sisters'/brothers' children.

English and Italian languages are more confusing while speaking about a person's spouse and his/her relatives. This is because the same word has different meanings and is used to describe several relations. Everything is clear for the words "wife" and "husband", in case of the "spouse" there are 2 words in Italian - "la coniuge" and "il coniuge" and the plural form - "I coniugi" - for both "wife and husband", which is not an exact word in English.

\footnotetext{
${ }^{32}$ Brown S., Relationship Terms, Oak Road Systems, 2016.

33 Ibid.
} 
In Armenian the roots "mother/father" are not used in the words naming "mother-in-law/father-in-law" and the nouns differ for the parents of a husband and a wife. Some people just say "mother, father" but number of these people is getting reduced. It is kept mainly in traditional villages. Also, mother-in-law (both for wife and husband) has sarcastic connotation, usually associated with not cheerful relationship between mothers-in-law and the sons/daughters-in-law. It is interesting that it does not exist in case of fathers-in-law. This can be explained in the frames of theory of stigmatization - after giving stigmas to a certain person, he/she starts to behave according to stigma. In Italian "il suocero" and "la suocera" are also used for both parents. "I suoceri" is the Italian word for "parents-in-law", which does not exist in Armenian. In general referring collectively to the blood relatives of a spouse, in English there is a word "my inlaws" ${ }^{34}$, which does not exist in Armenian and in Italian.

The same situation is for the roots of sons/daughters/-in-law son/daughter, which shows warm relationship. In Armenian these are just other words without association to daughter/son. Besides, the husband/wife of person's sister/brother is also characterized by the same word, which differs in Italian and means "sister - in-law" and "brother - in -law". The root of the word is "sister", meantime it shows some distance and formality when we say "in law". In Armenian, the noun describing this relationship is without the root "sister". It is just another, monosyllabic word without any association with "sister". The same is for "brother-in-law". In English the formation is the same for both "sister (brother)-in-law", in Italian even the root of the word is the same "cognato/cognata".

"Sister-in-law" and "brother-in-law" are among the most confusing nouns denoting family relationship. In this sense Italian and English are very similar to each other. In Italian there are 2 words - "la cognata" and "il cognato" which are used mainly in all cases as "sister-in-law" and "brother-in-law". In English the same noun has different meanings, e.g. sister-in-law can be the woman married to someone's brother or sister, or the sister of someone's husband or wife ${ }^{35}$. So, the same word can be used in various situations and needs to be explained in which meaning it is used in a certain case. Similarly, brother -in-law can be the husband of your sister or brother, or the brother of your husband or wife, or the man who is married to the sister or brother of your wife or husband ${ }^{36}$. In Italian the word "la cognata" is also used for "wife of wife's brother" as well as "il cognato" for "husband of husband's sister", which do not have equivalents in Armenian. It is also important that in Armenian all these relations are characterized with special words, like untiqn [tegr] - brother of husband, unul [tal] sister of husband, ptîh [qeni] - sister of wife, uiłpaduq [anerdzag] - brother

\footnotetext{
${ }^{34}$ Brown S., Relationship Terms, Oak Road Systems, 2016.

${ }^{35}$ Cambridge Dictionary, https://dictionary.cambridge.org/it/dizionario/inglese-italiano/sister-inlaw, accessed 10.11.2019.

${ }^{36}$ Ibid.
} 
of wife. Interesting point is that there are special words for the wife of husband's brother (untipuulhy [tegrakin]) and for husband of wife's sister (ptiuuluul [qenakal]) (the last one exists even in 2 forms - purquiuun [badganagh], but these words do not exist in case of husband of husband's sister and wife of wife's brother.

In English the noun "stepparents" can be considered as a neutral description of the current spouses of parents, meanwhile, in Armenian it literally means "alien/strange parents" which show the distance between parents and children. This is because of traditional relations in the Armenian society which does not positively accept divorces and new marriages. In Italian there are 2 words describing each relation in this sense, e.g. stepfather - "Il patrigno" and "padre acquisito", which is more neutral word, or "la sorellastra" and "sorella acquisita". It is also important that "matrigna", more than "patrigno", has a negative connotation, "sorellastra" as well, more than "fratellastro".

The interconnections of the words in these languages in interesting for "foster parents" and "foster children". In Armenian among all the words "foster parents", "foster mother", "foster father", "foster child", "foster son", "foster daughter" exist only "foster child" (the one that does not exist in Italian), meanwhile in Italian, except for "foster son" and "foster daughter" all the other nouns have two versions, e.g. "foster mother" is "madre adottiva" and "madre affidaria". This is mainly because adoption is not spread in Armenia and there is no need to have the words describing these relations.

The "godfather" and "godmother" have 2 versions in Armenian - one of them is formal version, the other sounds mainly like a status that is used to describe the importance of a godfather. The roots of the formal versions are "mother" and "father", the same is for Italian versions, but the non-formal version is composed of a monosyllabic word.

So, coming to the conclusion, the article aimed to analyze the nouns denoting family relations in Italian, Armenian and English languages. As it was described in the theoretical part, according to Giddens's theory, as the society is constructed through language, the existence or absence of a certain noun effect on the way people relate to some roles. By the way, these nouns were defined as restricted codes - used by whole members of society and through them it is possible to speak about society. It was already mentioned, that the way people refer to others, define the way of communication.

It is important to pay attention on the structure of a family: in extended families, where people live with their relatives, the interactions become closer. So, people refer to each other with closer nouns, like instead of a cousin brother or sister, etc. The existence of separate words for "aunt" and "uncle" (sister/brother of mother/father) in Armenian also approves that. Meantime, the absence of words "nephew" and "niece" also can show the prioritization of the roles of sister or brother and not their children in this relation. 
English and Italian languages are more confusing while speaking about a person's spouse and his/her relatives. This is because the same word has different meanings and is used to describe several relations. At the same time, in Armenian each relation has its own word to be described by. For example, people do not need to name "sister-in-law" (or the Italian equivalent "la cognata") the wife of their brother, or the sister of their wife, or the sister of their husband: in Armenian all these relations have their own nouns.

In case of "sister- in-law" and "brother - in -law", it is also interesting, that the root of the word is "sister" or "brother", meantime it shows some distance and formality when we say "in law". The same is for "mother-in-law" and "father-in-law". Meanwhile, according to some traditions, especially in Armenian villages daughters-in-law contact with their mothers/fathers-in-law by saying "mother" or "father". Of course, another important factor explaining this is the education level which also effect on the way of communication.

It is also important to mention, that in English the noun "stepparents" can be considered as a neutral description of the current spouses of parents, meanwhile, in Armenian it literally means "alien/strange parents" which show the distance between parents and children. This is because of traditional relations in the Armenian society which does not positively accept divorces and new marriages.

The analysis shows that in Armenian each relation has its own word to be described with, which means that roles in families are more important for Armenians, there is need in the society to name these relations. Besides, the society is more collectivistic and the role of a group and a family is important in the society. Meanwhile, in English and in Italian the nouns are commonly used to refer to many categories of people as family roles are not as much important in individualistic societies.

Key words: sociolinguistics, comparative analysis, English, Italian, Armenian, family relations, A. Giddens, B. Bernstein, sociology

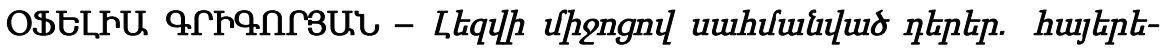

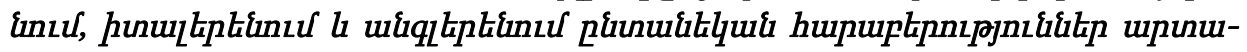

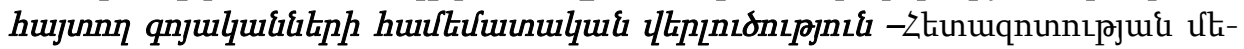

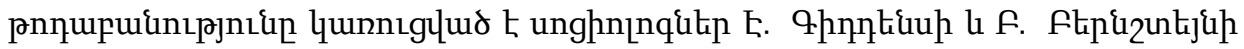

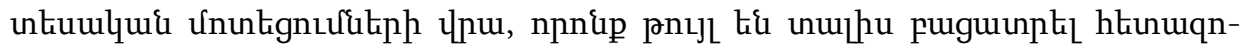

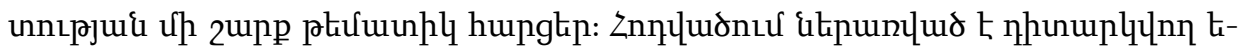

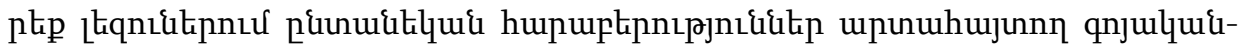

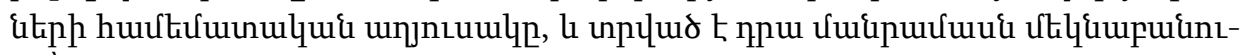

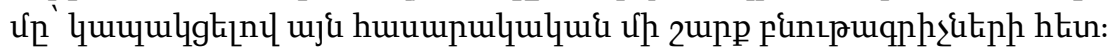

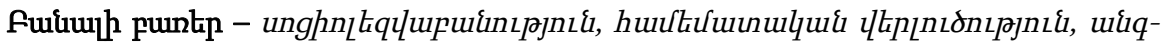

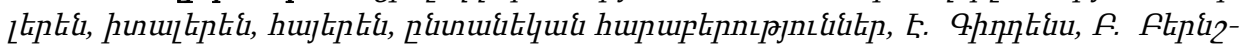
untigl, unghnlnqhu 
ОФЕЛИЯ ГРИГОРЯН - Роли, определенные языком: Сравнительный анализ существительных, выражающих семейные отношения на армянском, итальянском и английском языках. - В статье предпринята попытка сравнить существительные, выражающие семейные отношения на армянском, итальянском и английском языках, и выявить социальные основы их существования. Методология исследования построена на теоретических подходах социологов Э. Гидденса и Б. Бернштейна, которые позволяют нам объяснить ряд тематических вопросов исследования. В статье приведена сравнительная таблица существительных, выражающих семейные отношения на трех рассматриваемых языках, и дана детальная интерпретация этого в отношении ряда социальных характеристик.

Ключевые слова - сочиолингвистика, сравнительный анализ, английский, итальянский, армянский, семейные отношения, Э. Гидденс, Б. Бернштейн, сочиология, язык

'thplqujughltit k' 17.04.2020

9pulpunultel t' 14.06.2020

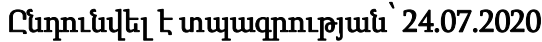




\begin{abstract}
The article attempts to compare nouns expressing family relations in Armenian, Italian and English, and to identify the social foundations of their existence. The research methodology is based on the theoretical approaches of sociologists E. Giddens and B. Bernstein, which allow us to explain a number of thematic research issues. The article provides a comparative table of nouns expressing family relations in the three languages under consideration, and gives a detailed interpretation of this in relation to a number of social characteristics
\end{abstract}

Keywords: sociolinguistics, comparative analysis, English, Italian, Armenian, family relations, A. Giddens, B. Bernstein, sociology

\title{
About Authors
}

Sonya Msryan - Ofelia Grigoryan - PhD student of the Chair of Theory and History of Sociology, Yerevan State University

E mail: ofelia_grigoryan@ysu.am

\section{REFERENCES}

Coupland, N., Sarangi, S. \& Candlin, C. (2001) Sociolinguistics and Social Theory, Longman, University of Michigan, p. 30.

Levi-Strauss, Cl. (1951) Language and the Analysis of Social Laws, American Anthropologist, New Series, Vol. 53, No. 2, pp. 155-163. Doi: https://doi.org/10.1525/aa.1951.53.2.02a00010 Coupland, N. (2007) Style: Language variation and identity, Cambridge, New York: Cambridge University Press, 2007, p. 128. Doi: https://doi.org/10.1017/CBO9780511755064 Giddens, A. (1984) The Constitution of Society. Outline of the Theory of Structuration. University of California Press.

Poole, M. (2013) Structuration Research on Group Communication, Management Communication Quarterly. 27, 4, pp. 607-614. Doi: https://doi.org/10.1177/0893318913506265 Poole, M. (1997) The Small Group Should Be the Fundamental Unit of Communication Research. In Trent, J. (Ed.), Communication: Views from the Helm for the 21st Century, Boston, MA: Allyn \& Bacon, pp. 94-97.

McPhee, R., Poole, M. \& Iverson, J. (2014) Structuration Theory In Putnam, L. \& Mumby, D. (Ed.), The SAGE Handbook of Organizational Communication: Advances in Theory, Research and Methods, pp. 75-101.

Albano, R., Masino, G. \& Magi, B. (2010) The Relevance of Giddens' Struturation Theory for Organizational Research, TAO Digital Library, Bologna.

Jones, M. R. \& Karsten, H.(2008) Giddens's Structuration Theory and Information Systems Research. MIS Quarterly, 32(1), 127-157. Doi: https://doi.org/10.2307/25148831 Pozzebon, M. \& Pinsonneault, A. (2005) Challenges in Conducting Empirical Work Using Structuration Theory: Learning from IT research. Organization Studies 26 (9), pp. 1353-1376. Doi: https://doi.org/10.1177/0170840605054621 
Bernstein, B. (1971) Class, Codes and Control (Volume 1) Theoretical Studies Towards a Sociology of Language. London: Routledge \& Kegan Paul.

Zhao, W (2014) The Implications of Bernstein's Theory of Codes on Contemporary Chinese Education, Canadian Social Science Vol. 10, No. 6, pp. 99-103.

Halliday, M. (2014) Language and the Theory of Codes. A. Sadovnik (Ed.) Knowledge and Pedagogy: The Sociology of Basil Bernstein. Westport, CT: Greenwood Publishing Group.

Maton, K. \& Muller, J. (2007) A sociology for the transmission of knowledges, Christie, F. \& Martin, J. (eds) Language, Knowledge and Pedagogy. London, Continuum, pp. 14-33.

Bernstein, B. (2010) A Public Language: Some Sociological Implications of a Linguistic Form, The British Journal of Sociology, Vol. 61. Doi: https://doi.org/10.1111/j.14684446.2009.01240.x

Bruner, J., Goodrow, J. \& Austin, A. (1957) A Study of Thinking, Wiley. Doi: https://doi.org/10.2307/1292061

Davis, A. et al (1951) Intelligence and Cultural Differences, University of Chicago Press. Bott, E. (2001) Family and Social Network: Roles, Norms and External Relationships in Ordinary Urban Families, Routledge, p.3.

Bernstein, B. (1990) Class, Codes and Control (Volume 4) The Structuring of Pedagogic Discourse, p. 101.

Newman, D. \& Grauerholz, L. (2002) Sociology of Families, SAGE Publications, p. 7.

Brown S. (2016) Relationship Terms, Oak Road Systems. 